\title{
Wool Keratin-Associated Protein Genes in Sheep-A Review
}

\author{
Hua Gong ${ }^{1,2}$, Huitong Zhou ${ }^{1,2}$, Rachel H. J. Forrest ${ }^{3}$, Shaobin Li ${ }^{1}$, Jiqing Wang ${ }^{1}$, \\ Jolon M. Dyer ${ }^{4}$, Yuzhu Luo ${ }^{1, *}$ and Jon G. H. Hickford ${ }^{1,2, *}$ \\ 1 International Wool Research Institute, Faculty of Animal Science and Technology, \\ Gansu Agricultural University, Lanzhou 730070, China; gonghua3000@gmail.com (H.G.); \\ zhouh@lincoln.ac.nz (H.Z.); lisb@gsau.edu.cn (S.L.); wangjq@gsau.edu.cn (J.W.) \\ 2 Gene-marker Laboratory, Faculty of Agricultural and Life Sciences, Lincoln University, \\ Lincoln 7647, New Zealand \\ 3 Faculty of Health and Sport Sciences, Eastern Institute of Technology, Private Bag 1201, \\ Napier 4142, New Zealand; rforrest@eit.ac.nz \\ 4 Food \& Bio-Based Products, Lincoln Research Centre, AgResearch Limited, Lincoln 7608, New Zealand; \\ dyerj@agresearch.co.nz \\ * Correspondence: yzluo@gsau.edu.cn (Y.L.); jon.hickford@lincoln.ac.nz (J.G.H.H.); \\ Tel.: +86-931-7632483 (Y.L.); +64-3423-0665 (J.G.H.H.)
}

Academic Editor: J. Peter W. Young

Received: 24 February 2016; Accepted: 25 May 2016; Published: 28 May 2016

\begin{abstract}
The importance of sheep's wool in making textiles has inspired extensive research into its structure and the underlying genetics since the 1960s. Wool keratin-associated proteins (KAPs) are a key structural component of the wool fibre. The characterisation of the genes encoding these proteins has progressed rapidly with advances in the nucleotide and protein sequencing. This review describes our knowledge of ovine KAPs, their categorisation into families, polymorphism in the proteins and genes, the clustering and chromosomal location of the genes, some characteristics of gene expression and some potential effects of the KAPs on wool traits. The extent and nature of genetic variation in wool KAP genes and its association with fibre characteristics, provides an opportunity for the development of gene-markers for selective breeding of sheep to produce better wool with properties highly matched to specific end-uses.
\end{abstract}

Keywords: Keratin-associated protein (KAP); polymorphism; expression; wool fibre; wool traits; sheep

\section{Introduction}

Wool is a natural fibre with unique attributes. It is widely used in the apparel, insulation and carpet industries, and humans have long recognised the benefits of wool, including its thermal attributes, breathability and fire resistance [1].

Wool fibre is primarily composed of proteins called hard $\alpha$-keratins [2]. These have a high sulphur content, consistent with having a high relative abundance of the amino acid cysteine. In wool, the $\alpha$-keratins are assembled into keratin intermediate filaments (KIFs), before being embedded in an inter-filamentous matrix containing keratin-associated proteins (KAPs). There are also other protein components in wool, such as trichohyalin, which is located in the inner root sheath and the medulla of the fibre, but these proteins are not regarded as essential to the fibre structure [2].

The earliest attempt to identify and classify wool proteins was made in 1935 [3], and it divided the major wool components into two classes of extractable protein: S-carboxy methyl kerateine A (SCMK-A) and S-carboxy methyl kerateine B (SCMK-B). These were of lower and higher sulphur 
content than the average sulphur content of wool respectively, and subsequently the SCMK-As were found to be the hair and wool $\alpha$-keratins, while the SCMK-Bs were the KAPs [4].

KAPs interact with the KIFs during fibre development and covalently bind with the KIFs through extensive disulphide bond cross-linking between cysteine in the KAPs and in the head and tail domains of the keratins [5]. Bundles of KIFs, then combine with KAPs to form macrofibrils through further inter- and/or intra-molecular disulphide bond formation [6]. While the KAPs may have little, or no discernible effect on keratin IF structure, their effect on KIF assembly into larger arrays, is considered to be crucial [7]. It is therefore believed that KAPs play an important role in defining the physico-mechanical properties of the wool fibre.

The KAPs are small in size ( $c a .10-30 \mathrm{kDa}$ ) and while they typically possess a high cysteine content, they can also have a high glycine and tyrosine content $[5,8]$.

\section{The Complexity of Wool KAPs}

Electrophoretic analyses of the SCMK-Bs revealed that a large number of KAPs existed [5]. Seven KAPs with a high sulphur content (B2A or KAP1-1, B2B or KAP1-2, B2C or KAP1-3, BIIIA3 or KAP2-n, BIIIB2 or KAP3-1, BIIIB3 or KAP3-3 and BIIIB4 or KAP3-3) were initially isolated from wool and their amino acid sequences were determined [9-16] and two KAPs with a high glycine-tyrosine content were also isolated and characterised $[17,18]$.

With the advent of DNA cloning techniques, 16 gene sequences encoding KAPs of a high sulphur content [19-23] and a high glycine-tyrosine content [24-26] were discovered through the isolation of their cDNA or genomic sequences. The subsequent development of further gene technologies, together with the sequence information derived from other species, has led to the identification of another five high sulphur KAP genes [27-31] and four high glycine-tyrosine [32-34] KAP genes in sheep.

Sequence analyses suggest that the KAP sequences identified to date probably represent 27 different KAP family members (Table 1). However, the possibility cannot be ruled out that some of these 27 may represent different variants of the same gene, rather than being different family members. This was shown for the human KAP1 [35] and KAP4 [36] genes. This suggests that further investigation is required to confirm both the number and constituency of the families, especially as our current understanding of the wool KAPs is still limited. For example, there may be ovine KAP genes that have not been identified yet, especially given that 88 functional and 17 pseudo-KAP genes have now been described in the human genome [37-39]. This likely represents the complete number of KAPs in humans, although sequencing of more human genetic material from different races and genetic backgrounds may result in minor changes to this thinking. 
Table 1. Ovine keratin-associated proteins (KAP) protein and gene sequences identified.

\begin{tabular}{|c|c|c|c|c|c|c|c|}
\hline KAP Family & Category & KAP Member & Old Name & Acidity/Basicity (Isoelectronic Point) & Sequence Type & Sequence Accession Number & Reference \\
\hline \multirow[t]{7}{*}{ KAP1 } & HS & KAP1-1 & B2A & Acidic (5.9) & Protein * & P02438 & [13] \\
\hline & & & & & DNA & X01610 \# & [19] \\
\hline & & KAP1-2 & B2B & Neutral (7.0) & Protein & P02439 & [15] \\
\hline & & & & & DNA & HQ897973 \# & [29] \\
\hline & & KAP1-3 & $\mathrm{B} 2 \mathrm{C}$ & Neutral (7.3) & Protein & $711148 \mathrm{~A}$ & [14] \\
\hline & & & & & DNA & $\mathrm{X} 02925^{\#}$ & [19] \\
\hline & & KAP1-4 & B2D & Acidic (5.9) & DNA & X01610 \# & [19] \\
\hline \multirow[t]{3}{*}{ KAP2 } & HS & KAP2-1 & BIIIA3A, KAP2.12 & Basic (8.1) & Protein & P02443 & [16] \\
\hline & & KAP2-3 & BIIIA3 & Basic (8.1) & Protein & P02441 & [16] \\
\hline & & & & & DNA * & U60024 & Unpublished \\
\hline \multirow[t]{6}{*}{ KAP3 } & HS & КАР3-1A & BIIIB2 & Neutral (7.0) & Protein & P02446 & [9] \\
\hline & & КАР3-1B & BIIIB2 & Neutral (7.4) & DNA & M21099 & [20] \\
\hline & & KAP3-2 & BIIIB3 & Neutral (7.0) & Protein & P02444 & [11] \\
\hline & & & & & DNA* & M21100 & [20] \\
\hline & & KAP3-3 & BIIIB4 & Neutral (7.0) & Protein & P02445 & [12] \\
\hline & & & & & DNA & M21103 & [20] \\
\hline \multirow[t]{3}{*}{ KAP4 } & UHS & KAP4-1 & & ND & DNA* & X73462 & [22] \\
\hline & & KAP4-2 & & Basic (8.1) & Protein & & [5] \\
\hline & & KAP4-3 & & Basic (8.2) & DNA & EU239778 & [31] \\
\hline \multirow[t]{4}{*}{ KAP5 } & UHS & KAP5-1 & & Basic (7.9) & DNA & X55294 & [21] \\
\hline & & KAP5-2 & & ND & DNA * & & [4] \\
\hline & & KAP5-4 & & Basic (7.9) & DNA & X73434 \# & {$[23]$} \\
\hline & & KAP5-5 & & ND & DNA* & X73435 & [23] \\
\hline \multirow[t]{6}{*}{ KAP6 } & HGT & KAP6-1 & HGT type II & Basic (8.3) & DNA & M95719\# & {$[22]$} \\
\hline & & KAP6-2 & HCT tyne UI & Basic (8.2) & Protein * & & {$[18]$} \\
\hline & & & & & DNA & KT725827 \# & [34] \\
\hline & & KAP6-3 & & Basic (8.4) & DNA & KT725833\# & {$[34]$} \\
\hline & & KAP6-4 & & Basic (8.2) & DNA & KT725838 \# & [34] \\
\hline & & KAP6-5 & & Basic (8.1) & DNA & KT725841 \# & {$[34]$} \\
\hline KAP7 & HGT & KAP7-1 & HGT-C2 & Basic (8.7) & DNA & X05638 & [25] \\
\hline \multirow[t]{3}{*}{ KAP8 } & HGT & KAP8-1 & HGT-F & Basic (8.3) & Protein & P02448 & {$[17]$} \\
\hline & & & & & DNA & X05639\# & {$[25]$} \\
\hline & & KAP8-2 & & Acid (6.3) & DNA & KF220646 \# & [33] \\
\hline KAP11 & HS & KAP11-1 & & Basic (8.0) & DNA & HQ595347 \# & [27] \\
\hline KAP13 & HS & KAP13-3 & & Basic (9.4) & DNA & JN377429 \# & [28] \\
\hline KAP24 & HS & KAP24-1 & & Basic (8.5) & DNA & JX112014 \# & [30] \\
\hline
\end{tabular}

ND -Not determined as only a partial sequence is available. Partial sequences are indicated with *. All sequence accession numbers refer to the GenBank, except for $711148 \mathrm{~A}$ which refers to the EMBL. When multiple DNA sequences have been identified, only one for each family member is listed and indicated by \#. 


\section{The Categorisation and Classification of Wool KAPs}

Following the original classification into SCMK-A and SCMK-B, the KAPs were subsequently categorised into three groups according to their amino acid composition: the high sulphur (HS; $\leqslant 30 \mathrm{~mol} \%$ cysteine), the ultra-high sulphur (UHS; $>30 \mathrm{~mol} \%$ cysteine) and the high glycine/tyrosine (HGT; 35-60 mol\% glycine and tyrosine) groups [5]. They were then assigned into families based on amino acid sequence homology.

In general terms, the individual KAP families are distinguished by the cysteine, or glycine and tyrosine content, the type and number of amino acid repeat structures, and the occurrence of unique sequence motifs [8]. In humans, the 88 functional KAP genes identified have been assigned to 25 families: KAP1 to KAP27, but with the absence of KAP14 and KAP18, which have only been found in mice [37-39].

In sheep, 27 putative wool KAPs having been identified to date and these have been assigned into the following 11 families:

KAP1: KAP1 is a HS-KAP family that contains four members (KAP1-1, KAP1-2, KAP1-3 and KAP1-4) $[13,14,19,29]$. The number of members equals that described in humans $[8,40]$. The KAP1 family members are similar to each other and differ mainly in the number of conserved tandem decapeptide "QTSCCQPXXX" repeats in the N-terminal half of the proteins (Figure 1a). There are between three to five decapeptide repeats in KAP1-1 [41], whereas KAP1-2, KAP1-3 and KAP1-4 have three, two and five repeats, respectively $[29,42,43]$. There is an apparent loss of a five residue C-terminus tail in KAP1-2, compared to the other KAP1 proteins [29] and KAP1-1 and KAP1-4 are acidic KAPs, while KAP1-2 and KAP1-3 are neutral (Table 1).

KAP2: KAP2 is a HS-KAP family. Five family members have been described in humans [40], but only two protein sequences (BIIIA3A and BIIIA3) have been reported in sheep (Figure 1b). These ovine sequences share $95 \%$ homology.

BIIIA3A is referred to as the orthologue of human KAP2-1 [8], although the same human sequence was previously called KAP2.12 [5]. BIIIA3 is identical to the predicated amino acid sequence of a partial DNA sequence referred to as KAP2-3 (GenBank U60024). To date no ovine KAP2-2 gene has not been reported. Given that the KAP2 family is conserved in humans, with over $97 \%$ sequence identity between the family members [8,40], it is likely that these two wool KAP2 sequences represent two members of the same family. The KAP2 family members possess several cysteine-rich pentameric repeat structures (CCXPX) and length differences are also observed among family members in both sheep and humans. The KAP2 proteins are weakly basic (Table 1).

KAP3: There are three major (originally designated as BIIIB2, BIIIB3 and BIIIB4) and one minor (originally called BIIIB1) proteins described for ovine KAP3 [44]. The three major proteins have been isolated and sequenced $[9,11,12]$ and the gene sequences thought to encode the major proteins have also been identified [20]. These have been named KAP3-1, KAP3-2 and KAP3-3 representing BIIIB2, BIIIB3 and BIIIB4, respectively. Minor differences between the protein sequences and the gene sequences have been reported for each family member, which may reflect nucleotide variation in the genes, or alternatively sequencing errors. The BIIIB2 protein sequence (labelled as KAP3-1A) [9] appears to be different to the predicted amino acid sequence derived from translation of the BIIIB2 gene (labelled as KAP3-1B) [20], and shares only 94\% homology at the amino acid sequence level. Interestingly, these two proteins would appear to have different $\mathrm{pI}$ values (Table 1), so whether these two BIIIB2 sequences represent different family members, or are variant forms of the same family member, requires further investigation. The human KAP3 family contains three functional genes and one pseudogene [8,40]. KAP3-2 and KAP3-3 are very similar to each other, but different to KAP3-1 (Figure 1c). Little repetitiveness of structure is seen in this family and the proteins are generally neutral. 
(a)

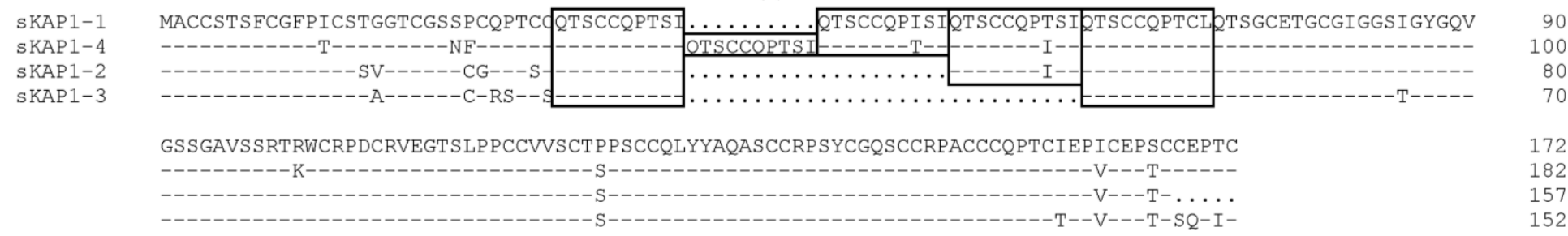

(b)

SKAP2-1* TGS CCGPTFSSLSCGGGCLQPCCYRDPOCCRPVSSTQTVSRPVTFVSRCTRPICEPCRRPYCCDPCSLQEGCCRPATCCPTSCQAVVCRPCCWATT CCQP SKAP2-3* ワSVQCE PCRP ISCPSAP. RTTCRTFRTSPCC

SKAP3-1A* .ACCAPRCCSVRTGPATTICSSDKFCRCGVCLPSTCPHNISLLQPT.CCDNSPVPCVYPDTYVPTCFLLNSSHPTPGLSGINLTTFIQPGCENVCEPRC SKAP3-1B
SKAP3-2*

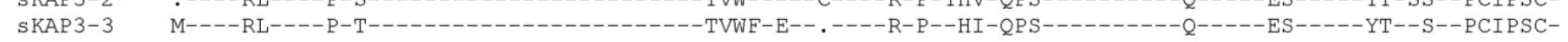

(d)

SKAP4-3 MVSSCCGSVCSDQSCGRSLCQETCCRPSCCQTTCCRTTCYRPSCGVSSCCRPVCCQPTCPRPTCYISSCSRPSCCVSSCGSSCYRPTGCISSCYRPQCCQ

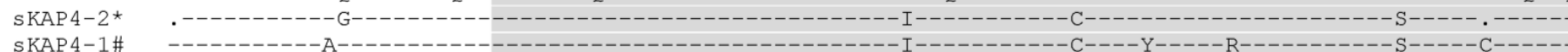

PVCCQPTCPRPTCCISSCRPRCCQPVCCQPTCPRPTCCISSCYRPSSCGSSCGSSCYRPTGCISSCYRPQCCQPVCCQPTCSRPTCCISSCYRPQCCQPV

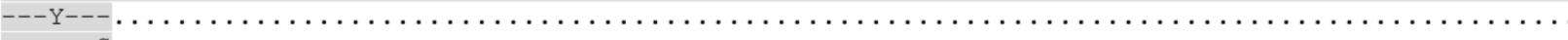

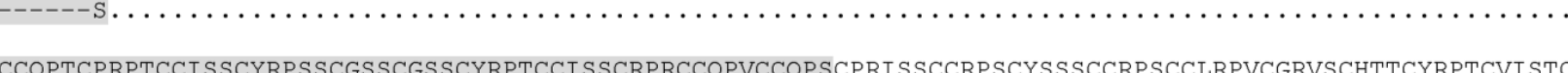
… PRPVSCPSSCC

$---------$ 
(e)

SKAP5-1

SKAP5-4

SKAP 5-5

SKAP 5-2\#

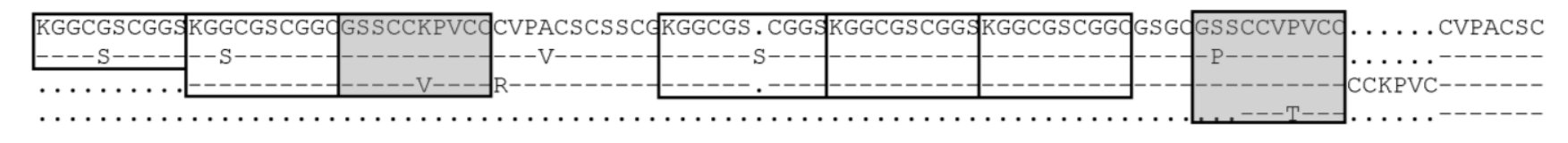

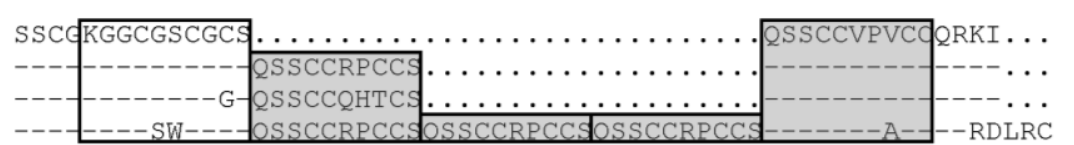

(f)

SKAP 6-1

SKAP6-2

SKAP 6-3

(1)

SKAP 6-4

s KAP 6-5

MCGYYGNYYGGLGCGSYSYGGLGCGYGSCYGSGFRLGCGYGCGYGYGSRSLCGSGYGYGSRSLCGSGYGCGSGYGSGFGYYY

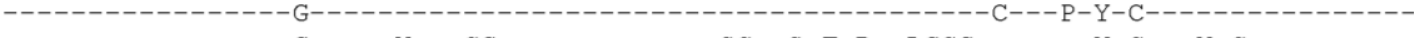

---

-

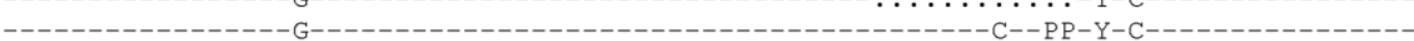

(g)

SKAP7 - 1

gKAP7-1

hKAP7-1

MTRFFCCGSYFPGYPSYGTNFHRTFRATPLNCVVPLGSPL . GYGCNGYSS LGYGFGGSSFSNLGCGYGGSFYRPWGSGSGFGYSTY

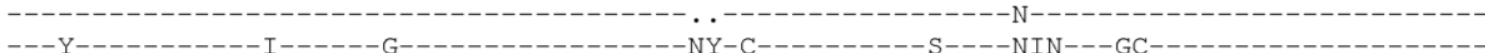

(h)

SKAP8-1

hKAP8-1

SKAP8-2

gKAP 8-2

M. SYCFSSTVFPGCYWGSYGYPLGYSVGCGYGSTYSPVGYGFGYGYNGSGA.SGCRRFWPFAIY

MLCDN-PGA--

MSCGF-NEGIY--Y----W---

MSGGF-NEGIY--Y----W-------

Figure 1. Cont 
(i)

SKAP11-1 (KAP11-1

CKAP11-1

MSYSCSTRNCSSRRIGGEYTVPVVTV. . . SSPDADCLSGIYLPSSFQ

TWLIDHCQETCCEPTVCOSTCYOPTPCVSSPVRVTSRQTTCV. SSPCSTTC -

SRPLTFISSGCQPLSGVSTVCKPVRSISTVCQPVGGVSTICQPTCGVSRTYQQSCVSSCRRIC

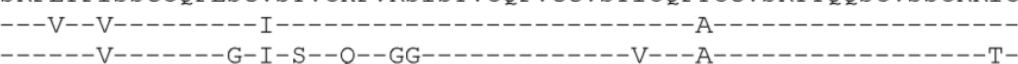

\section{(j)}

SKAP13-3 CKAP13-3 130

CKAP13-3

MSYNCCSRNFSSCSLGGHLRYSGSSCGSSFPRNLVYSTDLCPRSSCOLGSSLYSR . ETCCVPIRTOTFRVVSRPCOTSCRRRRTSTFSSPCKTTHHGS -------T------DR-S---

GCKSSSCSSLSSGSRRCYSVGCGSRVFRPLGYGVCGFPSLGCGSRFWHPINFPCRSFH $\ldots \ldots \ldots \ldots$

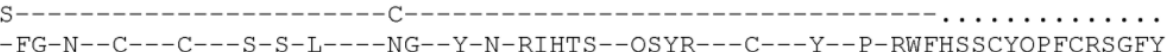

(k)

MAFIGYPGNCSGVSYRTHYYFPVTGSVALCSRHVSPTEGISIPSSYHGNLWLIDNCOETCGEAPTCESPCSEPKTC. TTTCDOSNSSVPCNSPTGGOICS S -STT----V--TT-----C-I---S--T-S-SDL-----HC-----Q-------Y---SY------K--SC-----S--G--P----------SA--VF

ARETTNIGPSLSCNQCPQTKGYVSDGCTPSRHTSKACQTLGNGFKCFGQLNCLSKSFQPLSHYRLGSFGYRSYQDLGFIPSGFSA.SRYITNSCQRQNYL VC----VS--P--SPST--N---CNCHI-T-NA-------R--SN------

RNSQCPYDWHRRCPPLSCFARNFRSLSSIPSSFPPLRYLYGGYRPLNCYRSTY....

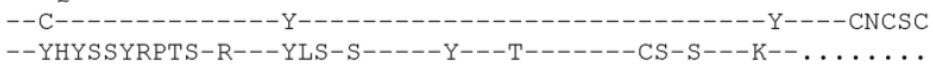

Figure 1. Amino acid sequence alignments of representative sequences from the ovine KAP families and orthologous sequences from other species. (a) KAP1-n; (b) KAP2-n; (c) KAP3-n; (d) KAP4-n; (e) KAP5-n; (f) KAP6-n; (g) KAP7-1; (h) KAP8-n; (i) KAP11-1; (j) KAP13-3; and (k) KAP24-1. The dashes represent amino acids identical to the top sequence and the dots act as spacers to improve alignments. The QTSCCQPXXX decapeptide repeat sequence found in KAP1-n and the CCVPX pentameric repeat sequence found in KAP2-n are shown in boxes. The central region consisting of contcatenates of nonocysteine- and dicysteine-containing pentameric repeats found in KAP4-n is shaded. In KAP5-n, the glycine-rich decapeptide repeat sequence is boxed, whereas the cycteine/serine-rich decapeptide repeat sequence is both boxed and shaded. All the amino acid sequences are predicated from DNA sequences, except for those indicated by * which were derived directly from protein sequencing. \# indicates a partial sequence. The sheep, goat, cattle and human sequences are indicated with a prefix of " $\mathrm{s}$ ", " $\mathrm{g}$ ", " $\mathrm{c}$ " and " $\mathrm{h}$ ", respectively. Accession numbers or references for the ovine sequences are shown in Table 1, and those from other species are: AB096962 (hKAP7-1); AY510121 (gKAP7-1); AP001709 (hKAP8-1); AY510123 (gKAP8-2); NM_001080740 (cKAP11-1); NW_001838706 (hKAP11-1); ENSBTAG00000040032 (cKAP13-3); NM_181622.1 (hKAP13-3); XM_002684598.1 (cKAP24-1) and NM_001085455 (hKAP24-1). 
KAP4: KAP4 is a UHS-KAP family. This family is reported to contain 11 members in humans [40], but only three members have been identified in sheep $[5,22,31]$. The ovine KAP4 proteins possess a repeat structure that covers a large portion of the middle section of the protein and consists of concatenates of a monocysteine- and dicysteine-containing pentameric repeat structure (Figure 1d). The proteins are weakly basic (Table 1).

KAP5: KAP5 belongs to the UHS group and is one of the largest KAP families, with 12 family members described in humans [8,37]. In sheep, three complete and one partial DNA sequences have been identified $[4,21,23]$ and these have been designated KAP5-1, KAP5-2, KAP5-4 and KAP5-5. Sheep KAP5 proteins possess repeat structures that are either cysteine/serine-rich, or glycine-rich, and the repeat number varies between family members (Figure 1e). The proteins are weakly basic (Table 1).

KAP6: KAP6 is a HGT-KAP family. Three family members have been identified in the human genome [45]. Southern-hybridisation analysis revealed that there were potentially several family members in sheep and as many as twenty in mice [26]. Early research identified two ovine members designated KAP6-1 and KAP6-2 [18,26], but three additional members (designated KAP6-3, KAP6-4 and KAP6-5) have recently been identified in the sheep genome and submitted to GenBank [34]. The KAP6 proteins consist of repetitive units of glycine-tyrosine and glycine-tyrosine-glycine (Figure 1f), and they are weakly basic (Table 1).

KAP7: KAP7 belongs to a HGT-KAP family. This KAP family contains only one family member designated KAP7-1 [25]. There is high sequence similarity between the orthologs from sheep and humans, and the number of glycine-tyrosine repeat structures is small compared to the KAP6 family (Figure 1g). Ovine KAP7-1 is basic, with a pI value of 8.7 (Table 1).

KAP8: KAP8 is a HGT-KAP family. In sheep, it was thought to contain only one member [25], but another potential member called KAP8-2 [33] has recently been identified. In humans only one KAP8 gene has been identified [45]. KAP8 proteins exhibit high sequence similarity across species, but have fewer glycine-tyrosine repeat structures when compared to the KAP6 family (Figure 1h). KAP8-2 contains a high content $(4.8 \mathrm{~mol} \%$ ) of aspartic acid and glutamic acid, which is not common in other HGT-KAPs, and hence it has a low pI value of 6.3 [33]. In sheep, KAP8-1 is weakly basic, while KAP8-2 is weakly acidic (Table 1).

KAP11: KAP11 is a HS-KAP family consisting of a single member categorised as KAP11-1 [27]. While KAP11-1 belongs to the HS group, the protein contains a low frequency of the "CCXP" motif that is common in the other cysteine-rich KAPs, and that is often found as part of longer repeat elements [5]. This motif is present in a single copy in KAP11-1 from sheep, cattle and humans, but it is absent in mouse KAP11-1. The KAP11-1 protein does not have a high content of glycine, but instead has proportionally more serine and threonine residues (Figure 1i). These two amino acids make up over $30 \mathrm{~mol} \%$ of the residues in ovine KAP11-1 [27], but the biological function of having higher concentrations of serine and threonine is not known. As serine and threonine residues can be post-translationally phosphorylated, it may be associated with the phosphorylation of this protein. KAP11-1 is a weakly basic protein (Table 1).

KAP13: Belonging to the HS group, the KAP13 family has four members in humans [46], but only one member (KAP13-3) has been described in sheep [28]. Ovine KAP13-3 has a low sequence similarity to the human orthologues, and only a poorly conserved repeat structure is found (Figure 1j). Like KAP11-1, the ovine KAP13-3 protein contains a high content of serine and threonine, and many of these residues are potentially post-translationally modified. The ovine KAP13-3 protein contains more positively charged amino acids (arginine, lysine and histidine) and fewer negatively charged ones (aspartic acid and glutamic acid), and hence it has a pI value of 9.4 [28]. It is the most basic KAP protein identified to date in sheep (Table 1).

KAP24: There is only one member (KAP24-1) reported in sheep [30] and in humans [38]. While probably belonging to the HS group, the KAP24-1 protein contains a moderate level of cysteine, but a high content of serine and tyrosine. High tyrosine contents are typically not observed in other HS or UHS KAPs and additionally, the tyrosine in KAP24-1 is not part of the dimeric glycine-tyrosine 
repeats that are found in other high glycine-tyrosine KAPs [30]. Wool KAP24-1 is a basic protein (Table 1) and it has a low ( 64\%) sequence similarity to the human orthologue. The human KAP24-1 protein possesses a series of tandem decameric repeat structures at the C-terminal end [38], but similar structures are not obvious in the ovine KAP24-1 sequence (Figure 1k).

\section{The Chromosomal Location of Wool KAP Genes}

The detection of multiple KAP genes in single genomic clones from a variety of mammalian species, immediately suggested the grouping of KAP genes in the genome $[19,21,47,48]$. More recent bioinformatic analyses of genome sequences have confirmed this clustering in humans $[40,45,49-51]$ and in a variety of others species [29,30,33,52].

The ovine KAP genes identified to date have been mapped to, or located on, three chromosomes. The KAP1-n, KAP3-n and KAP4-n genes are located on OAR11 [29,53,54]; the genes for the KAP6-KAP8, KAP11, KAP13 and KAP24 families are located on OAR1 [27,30,33,34,53]; and the KAP5-n genes are located on OAR21 [53,54] (Figure 2). The location of the KAP2-3 and KAP5-5 genes has not been determined, as only partial DNA sequences are available. The clustering and relative position of the various ovine KAP genes identified appears to correspond closely with that reported in humans $[8,38]$.
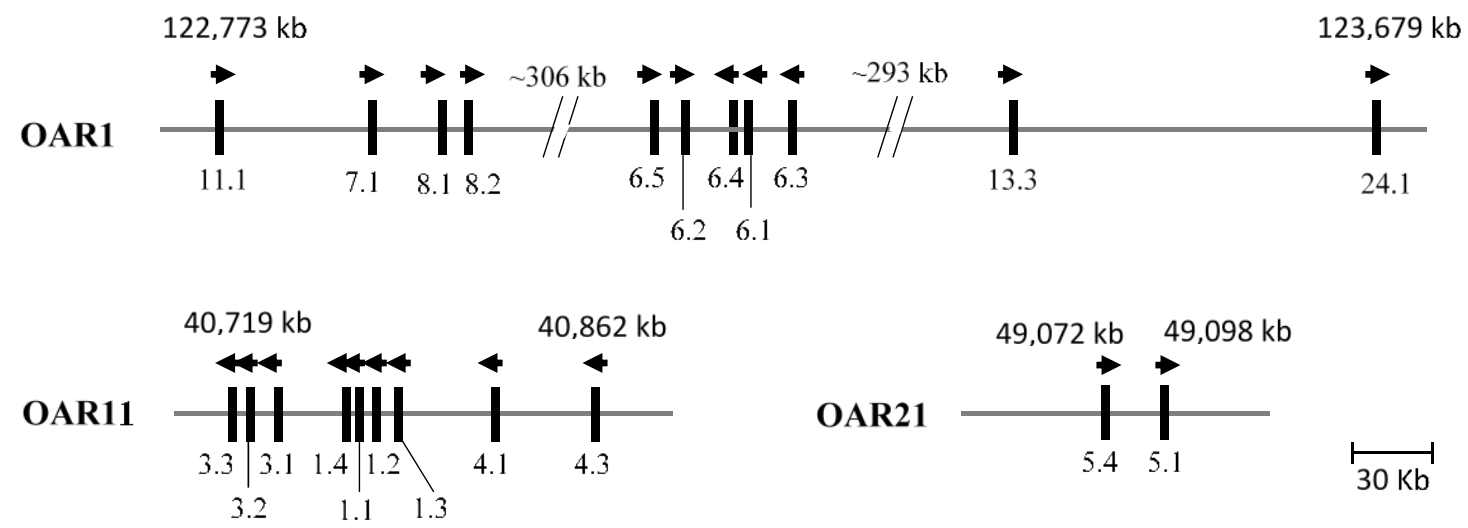

Figure 2. Clustering of the ovine KAP genes in three chromosome regions. The bolded vertical bars represent known KAP genes and the arrows indicate the direction of transcription. The numbers below these bars are the KAP gene names (i.e., 11.1 refers to KRTAP11-1). The spacing of the genes is only approximate and is based on the Ovine Genome Sequence Assembly v4.0 sequence, where coordinates are given for the boundaries of the clusters, based on the first and last gene identified in the group.

\section{Nucleotide Polymorphism within the KAP Genes}

While the KAP genes (denoted as KRTAPs) have been identified in humans, only limited efforts have been made to fully understand the presence of nucleotide variation within those genes. To date, it has only been described for the KAP1 and KAP4 families and studies only undertaken in Caucasian and Japanese populations $[8,35,36]$. In contrast, variation has been extensively looked for in ovine KAP genes, including KAP1, KAP3, KAP5, KAP6-KAP8, KAP11, KAP13 and KAP24 genes. This likely reflects the importance of wool in the production of apparel and interior textile products.

In the KAP1 family, three variant sequences containing 13 SNPs and length variation (having between three to five repeats of a 30 bp sequence) have been described for KRTAP1-1 [41,42], 11 variant sequences containing 10 SNPs have been described for KRTAP1-2 [29,55], nine variant sequences containing 20 SNPs have been described for KRTAP1-3 [41,42] and nine variant sequences containing 14 SNPs have been reported for KRTAP1-4 [43].

The SNPs described in KRTAP1-1 and KRTAP1-4 are predominantly non-synomynous, whereas those decribed in KRTAP1-2 and KRTAP1-3 are predominantly synomynous. This appears to reflect the chromosomal locations of these genes, where KRTAP1-1 and KRTAP1-4 are close to each other 
on the chromosome and further removed from KRTAP1-2 and KRTAP1-3 [29]. It should however be noted that the sequence variants described for KRTAP1-1 have been detected by PCR and agarose gel electrophoresis. This approach is inadequate for detecting SNPs and thus the varation described to date for KRTAP1-1 may be an under-estimation of what actually exists in sheep. Further investigation using other nucleotide variation screening techniques is required to reveal the full extent of variation in this gene, if it exists.

In the KAP3 family, variation has only been revealed in KRTAP3-2 [53]. Two variants of ovine KRTAP3-2 detected by PCR-SSCP have been reported, but as no sequence information describing the nucleotide varation has been reported, the nature of the variation is currently unknown.

In the KAP5 family, five sequnec variants have been decribed for ovine KRTAP5-4 [56]. There are six SNPs and one length polymorphism in this gene. Non-synonymous SNPs predominate and there is variation in copy number of a 30-bp repeat sequence encoding a cysteine-rich decapeptide "RPCCSQSSCC" in the C-terminal region. Either one, or two copies of the repeat sequence are present in each varaint.

In the KAP6 family, variaton has been investigated in all of the family members $[32,34,57]$. KRTAP6-1 has been described to have three sequence variants that are comprised of three SNPs and a 57-bp insertion/deletion [32,57]. KRTAP6-2 has six sequence variants containing five SNPs [34]. Five sequence variants are detected for KRTAP6-3. There are three SNPs and a 45-bp insertion/deletion observed for KRTAP6-3 [34]. KRTAP6-4 has been reported to have three SNPs resulting in three sequence variants [34]. There are six sequence variants described for KRTAP6-3 that contain five SNPs and an 18-bp insertion/delection [34]. The SNPs found in KRTAP6-3 and KRTAP6-5 are predominantly non-synonymous, whereas synonymous SNPs predominate in KRTAP6-1, KRTAP6-2 and KRTAP6-4. The nature of the polymorphism does not appear to coincide with the physical locations of the genes on the chromosome, but it is in some respects consistent with KRTAP6-1, KRTAP6-2 and KRTAP6-4 being located in the middle of a region that is flanked by KRTAP6-5 and KRTAP6-3.

Variation in KRTAP7-1 has been investigated by two groups [53,58]. McLaren et al. [53] reported two sequence variants using the restriction endonuclease $B g l I I$ and four sequence variants using the restriction endonuclease MspI in Southern hydridisation-Restriction Fragment Length Polymorphism (RFLP) analysis. No specific information on nucleotide sequence variation was given. Gong et al. [58] used PCR-SSCP to screen the entire coding region of KRTAP7-1 and reported two sequence variants resulting from one non-synonymous SNP. This SNP is not in either a nominal BglII or MspI restriction endonuclease recognition site. What is more, there are no BglII recognition sequences present, or that can be created by a single nucleotide substitution in the coding region of ovine KRTAP7-1. This suggests that these restriction endonuclease recognition sites were located outside of the coding region of the KRTAP7-1 gene.

In the KAP8 family, varation has been investigated in both KRTAP8-1 and KRTAP8-2 [33,58]. KRTAP8-1 has five sequnce variants containing four SNPs, whereas KRTAP8-2 has only two sequnce variants containing one SNP. The majority of SNPs found in KRTAP8-1 are synonymous [58], while the sole SNP found to date in KRTAP8-2 is located $21 \mathrm{bp}$ upstream of the nominal TATA box sequence [33].

Six and five sequnce variants are identified in ovine KRTAP11-1 and KRTAP13-3, respectively [27,28]. There are five and four SNPs in these genes respectively, and four of the five SNPs in KRTAP11-1 are synonymous, while three of the four SNPs in KRTAP13-3 are non-synonymous.

Using PCR-stem loop conformational polymorphism (PCR-SLCP), Zhou et al. [59] reported four sequnce variants of ovine KRTAP24-1. Seven SNPs were described in ovine KRTAP24-1 and four of them are non-synonymous.

In summary, variation has been found in all of the ovine KAP genes investigated to date. The apparent higher degree of variation found in sheep when compared to humans, is possibly due to a greater number of individuals having been screened. Genetic variation in human KAP genes could therefore potentially be significantly higher than previously thought based on comparison with ovine KAP genes, although this remains to be revealed. 


\section{The Expression of KAPs}

In humans, all the KAP genes that have been identified to date are expressed in the hair follicle, with the exception of families 16, 22, 25 and 27 [8,38,39]. These KAP genes exhibit a uniform hair follicle expression pattern that is characteristic of the chromosome domain in which these gene are located. The exception is for the KAP genes on chromosome domain 21q22.1 and a single KAP gene (KRTAP17-1) on chromosome 17q21.2 [8]. The detailed expression of human KAP genes has been reviewed [8] and will not be described here.

The expression of ovine KAPs is not well understood. Of the ovine KAP families investigated, the HGT-KAPs (KAP6, KAP7 and KAP8) are the first expressed in growing wool follicles and appear in the orthocortical cells [5,31]. The HS-KAPs (KAP1, KAP2 and KAP3) are initially expressed in the orthocortical cells, but soon after this are expressed in all cortical cells [5]. The UHS-KAP4 family is expressed later in follicle growth and only in paracortical cells [22,31]. The UHS-KAP5 family is expressed during cuticle differentiation [21,23]. A schematic summary of wool KAP expression is shown in Figure 3.

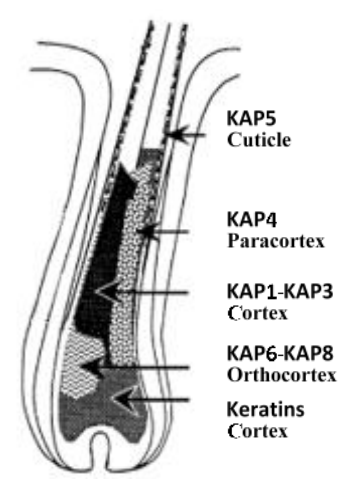

Figure 3. Schematic representation of the sites of KAP gene expression in the wool follicle. Modified from Powell and Rogers [5].

The expression of the KAP genes in sheep is consistent with that reported in humans, but some differences are observed. The most notable is the refined localisation of expression zones observed in wool follicles. For example, human KAP1 to KAP4, KAP6 and KAP7 are all expressed in the hair cortex [8], but in the wool follicle, KAP6 and KAP7 are only expressed in the orthocortex, and the expression of KAP4 is restricted to the paracortex [5,22,34]. While KAP1 and KAP2 are expressed across the entire cortex of wool follicles, their expression starts in the orthocortical half [5]. Such a well-defined bilateral expression pattern is not found in human hair follicles. In humans, KAP8 is expressed earlier than KAP6 and KAP7 [8], but they appear to be co-expressed in the wool follicle [5].

The weak expression of KAP6 in human hair [8] is of interest as it contrasts the high level of expression of KAP6 in the wool follicle. It should however be noted that the level of expression reported for the human KAP genes was based on the quantitation of mRNA level and not on the amount of protein observed in fibre [45]. It has been observed that there is only a moderate correlation between mRNA transcript levels and protein translation levels [60], and that the amount of mRNA present in a cell or tissue can be a poor predictor of protein levels, especially for genes with low mRNA expression. Equally, it has been reported that for some genes with similar levels of mRNA expression, the protein levels can vary 20- to 30-fold in difference [61].

\section{KAP Genes and Wool Traits}

There have been a number of studies describing associations between wool traits and variation in KAP genes. 
Wool crimp is thought to be affected by the composition of KAPs in the wool fibre. Felting lustre (FL) mutant wool has a very low relative abundance of HGT-KAP proteins in the fibre itself [62], but the genes encoding the HGT-KAPs are present [63]. This suggests a reduction or failure of transcription or translation of the HGT-KAPs genes in FL mutant wool. Research suggested originally that the FL mutation was inherited in a single autosomal dominant fashion [64], which was later confirmed by Blair [65]. However, examination of transcript prevalence, suggests that the KAP6-1, KAP7-1 and KAP8-1 genes are down-regulated, while the KAP2-12 and KAP4-2 genes are up-regulated in mutant follicles [66]. In the FL mutant follicles, there is only one type of cortical cell present (paracortical) and the orthocortical cell type where the HGT-KAPs are usually expressed appear to be absent [66]. A recent report by Wang et al. [67] describes an OAR11 QTL for crimp that is approximately $30 \mathrm{MB}$ from the known KAP genes on that chromosome.

Parson et al. [68] reported that variation in a KAP6 gene was associated with Mean Fibre Diameter (MFD) in medium wool Peppin Merinos. The KAP6 gene maps to ovine chromosome 1 [69] in a chromosome region where Beh et al. [70] detected a QTL affecting MFD in medium wool Merinos. On this chromosome, Roldan et al. [71] did not find any QTL for MFD, but instead they found a QTL for other wool traits including curvature and wool yield. Allain et al. [72] also detected a QTL on chromosome 1 for the "objectionable fibre content" (being defined as a large medulated fibres with a latticed medulla deficient in sulphur) in backcross Sarda $\times$ Lacaune sheep. Wang et al. [67] describe two chromosome 1 QTLs for fibre diameter, but they are at least $100 \mathrm{MB}$ from the known OAR1 KAP genes.

Recently, variation in KRTAP6-1 was found to be associated with variation in wool fibre diameter associated traits, and a 57-bp deletion in the gene was associated with the occurrence of coarser wool with a greater Fibre Diameter Standard Deviation (FDSD), a greater Coefficient of Variation of Fibre Diameter (CVFD) and increased Prickle Factor (percentage of fibres over 30 microns; PF) [57].

On ovine chromosome 11, Rogers et al. [73] reported a putative QTL for wool staple strength in the region spanning KRTAP1-1, KRTAP1-3 and KRT33A (KRT1-2) in Romney sheep. On this chromosome, Roldan et al. [71] detected a QTL for wool weight, staple strength and CVFD. Itenge-Mweza [74] reported an association between variation in KRTAP1-1 and wool yield in one half-sib family and with Mean Staple Length (MSL) and wool brightness in another half-sib family. An association between variation in KRTAP1-2 and Greasy Fleece Weight (GFW) and Clean Fleece Weight (CFW) was revealed in a recent study, suggesting KRTAP1-2 mainly affects wool weights [55]. This is in agreement with a study in goats reporting that KRTAP1-1 which is near KRTAP1-2, affects cashmere yield [75].

Finally, Raadsma et al. [76] report that OAR1 contains a QTL for wool pigmentation. The QTL (LOD score 2.5) is located near markers MAF64 and CSSM4 (192-256 cM) on chromosome 1 and while these are proximal to the KAP genes on that chromosome, it would be difficult to mount an argument of how the KRTAPs affect wool pigmentation specifically. This is not to say they do not affect pigmentation.

These findings suggest that KAP genes have a significant effect on wool traits, with further investigation required to fully explore this potential. While Wang et al. [67] found SNPs that might be associated with specific wool traits as described above, another more recent study using a SNP chip across 84 predicted KAP and keratin genes (59 SNPs were tested), did not reveal any association with fleece weight, wool fibre diameter and fibre curvature [77]. A SNP chip of these size may not have sufficient resolving power to precisely identify variation in ovine KAP genes, as many of the genes are highly polymorphic, having multiple variant forms as a consequence of containing many SNPs and insertions/deletions.

Given that KAP genes are clustered and that all the ovine KAP genes described to date are polymorphic and potentially expressed in the wool fibre, it will undoubtedly be difficult to unravel and determine the effects of individual genes on wool traits. However, the discovery of associations between variation in KAP genes and fibre traits, may ultimately allow for the future development of 
gene-markers for improving wool quality and, thus, enable the production of wool with specifications and performance more closely matched to targeted end-uses.

Acknowledgments: This work was financially supported by FRST (C10X0710) and the Lincoln University Gene-Marker Laboratory. The Wool Research Organisation of New Zealand Inc. and New Zealand Wool Industry Charitable Trust Postgraduate Scholarship to H. Gong is acknowledged.

Conflicts of Interest: The authors declare no conflict of interest.

\section{References}

1. Leeder, J.D. Wool: Nature's Wonder Fibre; Australasian Textiles Publishers: Victoria, Australia, 1984.

2. Popescu, C.; Höcker, H. Hair-The most sophisticated biological composite material. Chem. Soc. Rev. 2007, 36, 1282-1291. [CrossRef] [PubMed]

3. Goddard, D.R.; Michaelis, L. Derivatives of keratin. J. Biol. Chem. 1935, 112, 361-371.

4. Powell, B.C.; Rogers, G.E. Hair keratin: Composition, structure and biogenesis. In Biology of the Integument; Bereiter-Hahn, J., Matoltsy, A.G., Richards, K.S., Eds.; Springer: Berlin, Germany, 1986; Volume 2, pp. 695-721.

5. Powell, B.C.; Rogers, G.E. The role of keratin proteins and their genes in the growth, structure and properties of hair. In Formation and Structure of Human Hair; Jollès, P., Zahn, H., Höcker, H., Eds.; Birkhäuser Verlag: Basel, Switzerland, 1997; pp. 59-148.

6. Rogers, G.E. Hair follicle differentiation and regulation. Int. J. Dev. Biol. 2004, 48, 163-170. [CrossRef] [PubMed]

7. Plowman, J.E. Proteomic database of wool components. J. Chromatogr. 2003, 787, 63-76. [CrossRef]

8. Rogers, M.A.; Langbein, L.; Praetzel-Wunder, S.; Winter, H.; Schweizer, J. Human hair keratin-associated proteins (KAPs). Int. Rev. Cytol. 2006, 251, 209-263. [PubMed]

9. Haylett, T.; Swart, L. Studies on the high-sulfur proteins of reduced Merino wool. Part III: The amino-acid sequence of protein SCMKB-IIIB2. Text. Res. J. 1969, 39, 917-929.

10. Elleman, T.C. Amino-acid sequence of a high-sulphur protein from wool. Nature 1971, 234, 148-148. [CrossRef]

11. Haylett, T.; Swart, L.; Parris, D. Studies on the high-sulphur proteins of reduced Merino wool. Amino acid sequence of protein SCMBK-IIIB3. Biochem. J. 1971, 123, 191-200. [CrossRef] [PubMed]

12. Swart, L.; Haylett, T. Studies on the high-sulphur proteins of reduced Merino wool. Amino acid sequence of protein SCMKB-IIIB4. Biochem. J. 1971, 123, 201-210. [CrossRef] [PubMed]

13. Elleman, T.C. The amino acid sequence of protein SCMK-B2A from the high-sulphur fraction of wool keratin. Biochem. J. 1972, 130, 833-845. [CrossRef] [PubMed]

14. Elleman, T.C. The amino acid sequence of protein SCMK-B2C from the high-sulphur fraction of wool keratin. Biochem. J. 1972, 128, 1229-1239. [CrossRef] [PubMed]

15. Elleman, T.C.; Dopheide, T.A. The sequence of SCMK-B2B, a high-sulfur protein from wool keratin. J. Biol. Chem. 1972, 247, 3900-3909. [PubMed]

16. Swart, L.S.; Haylett, T. Studies on the high-sulphur proteins of reduced Merino wool. Amino acid sequence of protein SCMKB-IIIA3. Biochem. J. 1973, 133, 641-654. [CrossRef] [PubMed]

17. Dopheide, T.A. The primary structure of a protein, component 0.62 , rich in glycine and aromatic residues, obtained from wool keratin. Eur. J. Biochem. 1973, 34, 120-124. [CrossRef] [PubMed]

18. Gillespie, J.M. The proteins of hari and other hard $\alpha$-keartins. In Cellular and Molecular Biology of Intermediate Filaments; Goldman, R.D., Steinert, P.M., Eds.; Plenum: New York, NY, USA, 1990; pp. 95-128.

19. Powell, B.C.; Sleigh, M.J.; Ward, K.A.; Rogers, G.E. Mammalian keratin gene families: Organisation of genes coding for the B2 high-sulphur proteins of sheep wool. Nucleic Acids Res. 1983, 11, 5327-5346. [CrossRef] [PubMed]

20. Frenkel, M.J.; Powell, B.C.; Ward, K.A.; Sleigh, M.J.; Rogers, G.E. The keratin BIIIB gene family: Isolation of cDNA clones and structure of a gene and a related pseudogene. Genomics 1989, 4, 182-191. [CrossRef]

21. MacKinnon, P.; Powell, B.; Rogers, G. Structure and expression of genes for a class of cysteine-rich proteins of the cuticle layers of differentiating wool and hair follicles. J. Cell. Biol. 1990, 111, 2587-2600. [CrossRef] [PubMed] 
22. Fratini, A.; Powell, B.C.; Hynd, P.I.; Keough, R.A.; Rogers, G.E. Dietary cysteine regulates the levels of messenger-rnas encoding a family of cysteine-rich proteins of wool. J. Investig. Dermatol. 1994, 102, 178-185. [CrossRef] [PubMed]

23. Jenkins, B.J.; Powell, B.C. Differential expression of genes encoding a cysteine-rich keratin family in the hair cuticle. J. Investig. Dermatol. 1994, 103, 310-317. [CrossRef] [PubMed]

24. Kuczek, E.; Rogers, G.E. Sheep keratins: Characterization of cDNA clones for the glycine + tyrosine-rich wool proteins using a synthetic probe. Eur. J. Biochem. 1985, 146, 89-93. [CrossRef] [PubMed]

25. Kuczek, E.S.; Rogers, G.E. Sheep wool (glycine + tyrosine)-rich keratin genes. Eur. J. Biochem. 1987, 166, 79-85. [CrossRef] [PubMed]

26. Fratini, A.; Powell, B.C.; Rogers, G.E. Sequence, expression, and evolutionary conservation of a gene encoding a glycine tyrosine-rich keratin-associated protein of hair. J. Biol. Chem. 1993, 268, 4511-4518. [PubMed]

27. Gong, H.; Zhou, H.; Dyer, J.M.; Hickford, J.G. Identification of the ovine KAP11-1 gene (KRTAP11-1) and genetic variation in its coding sequence. Mol. Biol. Rep. 2011, 38, 5429-5433. [CrossRef] [PubMed]

28. Gong, H.; Zhou, H.; Dyer, J.M.; Plowman, J.E.; Hickford, J.G.H. Identification of the keratin-associated protein 13-3 (KAP13-3) gene in sheep. Open J. Genet. 2011, 1, 60-64. [CrossRef]

29. Gong, H.; Zhou, H.; Yu, Z.; Dyer, J.; Plowman, J.E.; Hickford, J.G.H. Identification of the ovine keratin-associated protein KAP1-2 gene (KRTAP1-2). Exp. Dermatol. 2011, 20, 815-819. [CrossRef] [PubMed]

30. Zhou, H.; Gong, H.; Yan, W.; Luo, Y.; Hickford, J.G.H. Identification and sequence analysis of the keratin-associated protein 24-1 (KAP24-1) gene homologue in sheep. Gene 2012, 511, 62-65. [CrossRef] [PubMed]

31. Yu, Z.; Gordon, S.W.; Nixon, A.J.; Bawden, C.S.; Rogers, M.A.; Wildermoth, J.E.; Maqbool, N.J.; Pearson, A.J. Expression patterns of keratin intermediate filament and keratin associated protein genes in wool follicles. Differentiation 2009, 77, 307-316. [CrossRef] [PubMed]

32. Gong, H.; Zhou, H.; Hickford, J.G.H. Diversity of the glycine/tyrosine-rich keratin-associated protein 6 gene (KAP6) family in sheep. Mol. Biol. Rep. 2011, 38, 31-35. [CrossRef] [PubMed]

33. Gong, H.; Zhou, H.; Dyer, J.M.; Hickford, J.G.H. The sheep KAP8-2 gene, a new KAP8 family member that is absent in humans. SpringerPlus 2014, 3, 1-5. [CrossRef] [PubMed]

34. Zhou, H.; Gong, H.; Wang, J.; Dyer, J.M.; Luo, Y.; Hickford, J.G.H. Identification of four new gene members of the KAP6 gene family in sheep. Sci. Rep. 2016, 6, 24074. [CrossRef] [PubMed]

35. Shimomura, Y.; Aoki, N.; Schweizer, J.; Langbein, L.; Rogers, M.A.; Winter, H.; Ito, M. Polymorphisms in the human high sulfur hair keratin-associated protein 1, KAP1, gene family. J. Biol. Chem. 2002, 277, 45493-45501. [CrossRef] [PubMed]

36. Kariya, N.; Shimomura, Y.; Ito, M. Size polymorphisms in the human ultrahigh sulfur hair keratin-associated protein 4, KAP4, gene family. J. Investig. Dermatol. 2005, 124, 1111-1118. [CrossRef] [PubMed]

37. Rogers, M.A.; Schweizer, J. Human KAP genes, only the half of it? Extensive size polymorphisms in hair keratin-associated protein genes. J. Investig. Dermatol. 2005, 124, vii-ix. [CrossRef] [PubMed]

38. Rogers, M.A.; Winter, H.; Langbein, L.; Wollschläger, A.; Praetzel-Wunder, S.; Jave-Suarez, L.F.; Schweizer, J. Characterization of human KAP24. 1, a cuticular hair keratin-associated protein with unusual amino-acid composition and repeat structure. J. Investig. Dermatol. 2007, 127, 1197-1204. [CrossRef] [PubMed]

39. Rogers, M.A.; Langbein, L.; Praetzel Wunder, S.; Giehl, K. Characterization and expression analysis of the hair keratin associated protein KAP26.1. Br. J. Dermatol. 2008, 159, 725-729. [CrossRef] [PubMed]

40. Rogers, M.A.; Langbein, L.; Winter, H.; Ehmann, C.; Praetzel, S.; Korn, B.; Schweizer, J. Characterization of a cluster of human high/ultrahigh sulfur keratin-associated protein genes embedded in the type I keratin gene domain on chromosome 17q12-21. J. Biol. Chem. 2001, 276, 19440-19451. [CrossRef] [PubMed]

41. Rogers, G.R.; Hickford, J.G.H.; Bickerstaffe, R. Polymorphism in two genes for B2 high sulfur proteins of wool. Anim. Genet. 1994, 25, 407-415. [CrossRef] [PubMed]

42. Itenge-Mweza, T.O.; Forrest, R.H.; McKenzie, G.W.; Hogan, A.; Abbott, J.; Amoafo, O.; Hickford, J.G.H. Polymorphism of the KAP1.1, KAP1.3 and K33 genes in Merino sheep. Mol. Cell. Probs 2007, 21, 338-342. [CrossRef] [PubMed]

43. Gong, H.; Zhou, H.; Hickford, J.G. Polymorphism of the ovine keratin-associated protein 1-4 gene (KRTAP1-4). Mol. Biol. Rep. 2010, 37, 3377-3380. [CrossRef] [PubMed]

44. Swart, L.; Haylett, T.; Joubert, F. Studies on the high-sulfur proteins of reduced Merino wool. Part II1: The isolation of a homogeneous protein. Text. Res. J. 1969, 39, 912-917. 
45. Rogers, M.A.; Langbein, L.; Winter, H.; Ehmann, C.; Praetzel, S.; Schweizer, J. Characterization of a first domain of human high glycine-tyrosine and high sulfur keratin-associated protein (KAP) genes on chromosome 21q22.1. J. Biol. Chem. 2002, 277, 48993-49002. [CrossRef] [PubMed]

46. Rogers, M.A.; Winter, H.; Langbein, L.; Bleiler, R.; Schweizer, J. The human type I keratin gene family: Characterization of new hair follicle specific members and evaluation of the chromosome 17q21.2 gene domain. Differentiation 2004, 72, 527-540. [CrossRef] [PubMed]

47. Cole, S.E.; Reeves, R.H. A cluster of keratin-associated proteins on mouse chromosome 10 in the region of conserved linkage with human chromosome 21. Genomics 1998, 54, 437-442. [CrossRef] [PubMed]

48. Kuhn, F.; Lassing, C.; Range, A.; Mueller, M.; Hunziker, T.; Ziemiecki, A.; Andres, A.C. Pmg-1 and pmg-2 constitute a novel family of KAP genes differentially expressed during skin and mammary gland development. Mech. Dev. 1999, 86, 193-196. [CrossRef]

49. Rogers, M.A.; Langbein, L.; Winter, H.; Beckmann, I.; Praetzel, S.; Schweizer, J. Hair keratin associated proteins: Characterization of a second high sulfur KAP gene domain on human chromosome 21. J. Investig. Dermatol. 2004, 122, 147-158. [CrossRef] [PubMed]

50. Shibuya, K.; Obayashi, I.; Asakawa, S.; Minoshima, S.; Kudoh, J.; Shimizu, N. A cluster of 21 keratin-associated protein genes within introns of another gene on human chromosome 21q22.3. Genomics 2004, 83, 679-693. [CrossRef] [PubMed]

51. Yahagi, S.; Shibuya, K.; Obayashi, I.; Masaki, H.; Kurata, Y.; Kudoh, J.; Shimizu, N. Identification of two novel clusters of ultrahigh-sulfur keratin-associated protein genes on human chromosome 11. Biochem. Biophys. Res. Commun. 2004, 318, 655-664. [CrossRef] [PubMed]

52. Wu, D.D.; Irwin, D.; Zhang, Y.P. Molecular evolution of the keratin associated protein gene family in mammals, role in the evolution of mammalian hair. BMC Evol. Biol. 2008, 8, 241. [CrossRef] [PubMed]

53. McLaren, R.J.; Rogers, G.R.; Davies, K.P.; Maddox, J.F.; Montgomery, G.W. Linkage mapping of wool keratin and keratin-associated protein genes in sheep. Mamm. Genome 1997, 8, 938-940. [CrossRef] [PubMed]

54. Gong, H.; Zhou, H.; McKenzie, G.W.; Yu, Z.; Clerens, S.; Dyer, J.M.; Plowman, J.E.; Wright, M.W.; Arora, R.; Bawden, C.S. An Updated Nomenclature for Keratin-Associated Proteins (KAPs). Int. J. Biol. Sci. 2012, 8, 258-264. [CrossRef] [PubMed]

55. Gong, H.; Zhou, H.; Hodge, S.; Dyer, J.M.; Hickford, J.G.H. Association of wool traits with variation in the ovine KAP1-2 gene in Merino cross lambs. Small Rum. Res. 2015, 124, 24-29. [CrossRef]

56. Gong, H.; Zhou, H.; Plowman, J.E.; Dyer, J.M.; Hickford, J.G.H. Analysis of variation in the ovine ultra-high sulphur keratin-associated protein KAP5-4 gene using PCR-SSCP technique. Electrophoresis 2010, 31, 3545-3547. [CrossRef] [PubMed]

57. Zhou, H.; Gong, H.; Li, S.; Luo, Y.; Hickford, J.G.H. A 57-bp deletion in the ovine KAP6-1 gene affects wool fibre diameter. J. Anim. Breed. Genet. 2015, 132, 301-307. [CrossRef] [PubMed]

58. Gong, H.; Zhou, H.; Plowman, J.E.; Dyer, J.M.; Hickford, J.G.H. Search for variation in the ovine KAP7-1 and KAP8-1 genes using polymerase chain reaction-single-stranded conformational polymorphism screening. DNA Cell. Biol. 2011, 31, 367-370. [CrossRef] [PubMed]

59. Zhou, H.; Kunhareang, S.; Gong, H.; Fang, Q.; Hu, J.; Luo, Y.; Hickford, J.G.H. Detection of sequence variation and genotyping of polymorphic genes using polymerase chain reaction stem-Loop conformational polymorphism analysis. Anal. Biochem. 2011, 408, 340-341. [CrossRef] [PubMed]

60. Miklos, G.L.G.; Maleszka, R. Protein functions and biological contexts. Proteomics 2001, 1, 169-178. [CrossRef]

61. Gygi, S.P.; Rochon, Y.; Franza, B.R.; Aebersold, R. Correlation between protein and mRNA abundance in yeast. Mol. Cell. Biol. 1999, 19, 1720-1730. [CrossRef] [PubMed]

62. Gillespie, J.M.; Darskus, R.L. Relation between the tyrosine content of various wools and their content of a class of proteins rich in tyrosine and glycine. Aust. J. Biol. Sci. 1971, 24, 1189-1198. [PubMed]

63. Rogers, G.; Kuczek, E.; MacKinnon, P.; Presland, R.; Fietz, M. Special biochemical features of the hair follicle. In The Biology of Wool and Hair; Rogers, G.E., Reis, P.J., Ward, K.A., Marshall, R.C., Eds.; Chapman \& Hall: London, UK, 1989; pp. 69-85.

64. Short, B. A dominant felting lustre mutant fleece-type in the Australian Merino sheep. Nature 1958, 181, 1414-1415. [CrossRef] [PubMed]

65. Blair, H. Inheritance of a major gene for excessively lustrous wool in sheep. J. Hered. 1990, 81, $222-224$.

66. Li, S.W.; Ouyang, H.S.; Rogers, G.E.; Bawden, C.S. Characterization of the structural and molecular defects in fibres and follicles of the merino felting lustre mutant. Exp. Dermatol. 2009, 18, 134-142. [CrossRef] [PubMed] 
67. Wang, Z.; Zhang, H.; Yang, H.; Wang, S.; Rong, E.; Pei, W.; Li, H.; Wang, N. Genome-wide association study for wool production traits in a Chinese Merino sheep population. PLOS ONE 2014, 9, e107101. [CrossRef] [PubMed]

68. Parsons, Y.M.; Cooper, D.W.; Piper, L.R. Evidence of linkage between high-glycine-tyrosine keratin gene loci and wool fiber diameter in a merino half-sib family. Anim. Genet. 1994, 25, 105-108. [CrossRef] [PubMed]

69. Parsons, Y.M.; Piper, L.R.; Cooper, D.W. Linkage relationships between keratin-associated protein (KRTAP) genes and growth hormone in sheep. Genomics 1994, 20, 500-502. [CrossRef] [PubMed]

70. Beh, K.J.; Callaghan, M.J.; Leish, Z.; Hulme, D.J.; Lenane, I.; Maddox, J.F. A genome scan for QTL affecting fleece and wool traits in Merino sheep. Wool Technol. Sheep Breed. 2001, 49, 88-97.

71. Roldan, D.; Dodero, A.; Bidinost, F.; Taddeo, H.; Allain, D.; Poli, M.; Elsen, J. Merino sheep: A further look at quantitative trait loci for wool production. Animal 2010, 4, 1330-1340. [CrossRef] [PubMed]

72. Allain, D.; Schibler, L.; Mura, L.; Barillet, F.; Sechi, T.; Rupp, R.; Casu, S.; Cribiu, E.; Carta, A. QTL detection with DNA markers for wool traits in a sheep backcross Sarda $\times$ Lacaune resource population. In Proceedings of the 8th World Congress on Genetics Applied to Livestock Production, Belo Horizonte, Minas Gerais, Brazil, 13-18 August 2006; Instituto Prociência: Minas Gerais, Brazil, 2006; pp. 5-7.

73. Rogers, G.; Hickford, J.; Bickerstaffe, R. A Potential QTL for Wool Strength Located on Ovine Chromosome 11. In Proceedings of the 5th World Congress on Genetics Applied to Livestock Production, Guelph, ON, Canada, 7-12 August 1994; pp. 291-294.

74. Itenge-Mweza, T.O. Identification of Genetic Markers Associated with Wool Quality Traits in Merino Sheep. Ph.D. Thesis, Lincoln University, Christchurch, New Zealand, 2007.

75. Zhang, Y.; He, Y.; Xue, P.; Chen, Y. Sequence variant in the KAP1.1 gene associate with cashmere trait in two cashmere goat breeds. Afr. J. Agr. Res. 2011, 6, 2889-2894.

76. Raadsma, H.W.; Jonas, E.; Fleet, M.R.; Fullard, K.; Gongora, J.; Cavanagh, C.R.; Tammen, I.; Thomson, P.C. QTL and association analysis for skin and fibre pigmentation in sheep provides evidence of a major causative mutation and epistatic effects. Anim. Genet. 2013, 44, 547-559. [CrossRef] [PubMed]

77. Phuaa, S.H.; Scobieb, D.R.; O'Connellb, D.; Henrya, H.; Doddsa, K.G.; Brauninga, R.; Clerensb, S. Preliminary linkage studies in sheep of keratin and keratin-associated protein genes with fleece weight, wool fibre diameter and fibre curvature. Proc. N. Z. Soc. Anim. Prod. 2015, 75, 101-105. 